\title{
Current issues of diagnostics and development of the organization in the field of project management
}

\author{
Natalia Kataeva ${ }^{1,{ }^{*}, \text { Darya }}$ Starkova $^{2}$, Alexey Sysolyatin ${ }^{1}$, and Kristina Karmokova ${ }^{3}$ \\ ${ }^{1}$ Vyatka State University, Moskovskaya street, 36, Kirov city, Kirov region, 610000, Russia \\ ${ }^{2}$ Vyatka State Agricultural Academy, October Avenue,133,Kirov city, Kirov region, 610017, Russia \\ ${ }^{3}$ Moscow State University of Civil Engineering, 26 Yaroslavskoye Shosse, 109377, Moscow, Russia
}

\begin{abstract}
This article analyzes the aspects of competence approach in improving the skills of project managers, as well as the main approaches to the study of the organization's competence in the field of project management. Having applied generalization and systematization of different models of competence-based approach, the authors developed a mechanism for assessing the competence of the organization in the field of project management. The analysis concluded that increasing the level of organizational maturity and individual competence of project management specialists contributes to the growth of project culture and project implementation within the established limits and success criterion, and so, therefore, allows the organization to implement the set strategic objective, overcome the contemporary strategic challenges with a minimum of losses, improve the financial efficiency of the organization generally. Using the SOVNET methodology to assess the level of individual competence of employees and the organizational maturity model of project management, the close correlation and identity of these two values is proved as a percentage of the ideal level by the results of measurements on the example of an oil refining company.
\end{abstract}

\section{Introduction}

Most organizations of all sizes and in all industries have focused on successful project implementation for the past several decades. The world is becoming more complex and dynamic, and organizations must be prepared to meet the ever-increasing expectations of stakeholders through better management of projects, programs, and project portfolios. In addition, companies must be able to implement projects productively and effectively, so that with optimal usage of resources. Along with developing the competence of individual employees, they should also analyze and develop the competence of the organization as a whole.

As practice shows, simply training or hiring experienced project managers in the organization is not enough to increase the effectiveness of project activities, it is necessary

* Corresponding author: natalya-kataeva@yandex.ru 
to create an organizational environment that will support the implementation of projects and development programs.

The aim of the research is the analysis of level of project management specialists competence, determining the degree of correlation between the level of specialists competence in the field of project management and the economic results of the subject of petroleum products market, development of basic stages and a mechanism for assessing the level of competence of the organization in project management.

The theoretical and methodological foundations and approaches he definition of the concept of "competence" is considered in the works of Russian scientists in the field of project management I. S. Sergeev, J. Raven, S. Velde, A.V. Khutorsky, as well as in international standards ICB 3.0/4.0, ISO 17024, Project Manager Competency Development Framework [1,2,3,4,5,6].

The problems of methodological justification for assessing the competence of an organization in the field of project management have been addressed in the works of such scientists as: Y. N. Solovyova, A. K. Kupeshev, A. R. Shalbaeva, as well as in international standards for project management ICB 3.0/4.0, PMBOK $[6,7,8,9]$.

Great significance for the research had a study of the works, dedicated to the problems of competence formation in the field of project management and analysis of the oil supply market, among which should be highlighted works A. V. Koryakin, , N. N. Kataeva, O. V. Toporova $[10,11]$.

Despite the large number of scientific papers, the issues of diagnostics and development of the organization's competence in the field of project management are fragmentary. There are no specific guidelines in most works, at the same time, the existing approaches don't allow us to form a complete representation of the technique of diagnostics and formation of the organization's competence in the field of project management.

\section{Materials and methods}

The theoretical and methodological base was the conceptual research of main provisions of microeconomics, project management based on the use of a competence model to ensure effective adaptation of the company to changes in the external environment, its innovation, improving the quality and effectiveness of work on the of basis analytical and expert methods, which are presented in the domestic and foreign scientific literature [12].

To assess the level of competence of the organization's employees, a methodology SOVNET was chosen, which is based on the principles of the certification system IPMA standard ISB 4.0. Conclusions are based on the results of staff self-assessment of their knowledge, skills and abilities in three areas: context, people and practice.

This technique involves self-assessment of the level of knowledge (this implies not only correct reproduction of situations, but also an understanding of the relationships, the ability to apply theoretical knowledge in practical situations and interpret the methodology in relation to the actual conditions of a particular project) and employee experience in four main competence groups: management objects and contextual competencethe subjects of management and behavioural competence, management processes and technical competence, general (basic) competence [13].

A score scale from 0 (not competent) to 10 (absolutely competent) is used to evaluate knowledge and experience for each competency element. The criteria for rating on this scale are shown in table 1.

Justification of the main provisions of the process of assessing the level of competence of the organization in project management was carried out using traditional methods of deduction and induction, abstract - logical judgments and evaluations, a systematic 
approach. The empirical part of the work is based on the use of monographic methods of information analysis [14].

Table 1. Scale of assessment of employees ' knowledge and experience.

\begin{tabular}{|c|c|c|}
\hline Evaluation & Characteristics of the knowledge & Characteristics of the experience \\
\hline 0 & Absent & Absent \\
\hline $\begin{array}{l}1 \\
2 \text { low } \\
3\end{array}$ & $\begin{array}{l}\text { The candidate is familiar with the } \\
\text { knowledge element and can present and } \\
\text { explain the criteria for this element } \\
\text { Verbs: to recognize, to name, to list, to } \\
\text { structure, to describe, to define, to } \\
\text { explain, to find, to reproduce. } \\
\text { Nouns: terms, classes, facts, criteria, } \\
\text { standards, rules, methods, processes, } \\
\text { relationships. }\end{array}$ & $\begin{array}{l}\text { The candidate has some project } \\
\text { management experience that he or she } \\
\text { has acquired by performing a separate } \\
\text { role in projects within a single } \\
\text { economic sector or organizational unit } \\
\text { during one or more phases of these } \\
\text { projects. } \\
\text { Description: having some experience } \\
\text { as an assistant project Manager, in } \\
\text { some phases of several projects, with a } \\
\text { good knowledge of project } \\
\text { management. }\end{array}$ \\
\hline $\begin{array}{l}4 \\
5 \text { average } \\
6\end{array}$ & $\begin{array}{l}\text { The candidate has strong knowledge and } \\
\text { can recognize and apply the appropriate } \\
\text { criteria, as well as control the results. } \\
\text { Verbs: to apply, to use, to implement, to } \\
\text { calculate, to confirm, to interpret, to } \\
\text { distinguish, to find a solution. } \\
\text { Nouns: situations, applications, } \\
\text { principles, criteria, rules, methods, } \\
\text { conclusions. }\end{array}$ & $\begin{array}{l}\text { The candidate has an average level of } \\
\text { experience and professional } \\
\text { characteristics obtained as a result of } \\
\text { working in many important areas of } \\
\text { management of several projects, at } \\
\text { least in one important sector of the } \\
\text { economy during most phases of these } \\
\text { projects. } \\
\text { Description: significant experience in } \\
\text { a responsible management position, } \\
\text { participation in most phases of several } \\
\text { different projects of limited } \\
\text { complexity with good knowledge of } \\
\text { project management. }\end{array}$ \\
\hline $\begin{array}{l}7 \\
8 \text { high } \\
9\end{array}$ & $\begin{array}{l}\text { The candidate understands the role in } \\
\text { detail and is able to evaluate, create and } \\
\text { integrate appropriate criteria and is able } \\
\text { to interpret and evaluate the results. } \\
\text { Verbs: to analyze, to draw conclusions, } \\
\text { to develop, to combine, to compose, to } \\
\text { research, to evaluate, to weigh, to } \\
\text { suggest, to solve. } \\
\text { Nouns: situations, conditions, } \\
\text { assumptions, ideas, opinions, cases, } \\
\text { models, alternatives, problems, results, } \\
\text { procedures, solutions. }\end{array}$ & $\begin{array}{l}\text { The candidate has extensive } \\
\text { experience and a track record that has } \\
\text { been acquired through responsible } \\
\text { management of numerous projects of } \\
\text { various types in most or all phases of } \\
\text { these projects. } \\
\text { Description: comprehensive } \\
\text { experience in project management in } \\
\text { various positions with a high level of } \\
\text { responsibility, at most phases of } \\
\text { various projects and / or programs or } \\
\text { portfolios with a exhaustive } \\
\text { understanding of project management. }\end{array}$ \\
\hline 10 & Absolute maximum & Absolute maximum \\
\hline
\end{tabular}

\section{Results}

Let's consider the main approaches to the study of the organization's competence in the field of project management (table 2). According to the process approach, the organization's competence in project management is considered as a dynamic education, which is a component of professional competence and a criterion for the continuous development of professionalism. 
Table 2. Approaches to research competence in project management.

\begin{tabular}{|c|c|c|}
\hline Approach & $\begin{array}{l}\text { Elements of competence in project } \\
\text { management }\end{array}$ & $\begin{array}{l}\text { Indicators for assessing the level of } \\
\text { competence of the organization }\end{array}$ \\
\hline \multirow[t]{7}{*}{$\begin{array}{l}\text { Process } \\
\text { approach }\end{array}$} & $\begin{array}{l}\text { - creating and integrating } \\
\text { knowledge; }\end{array}$ & \multirow{7}{*}{$\begin{array}{l}\text { - efficiency of project activities; } \\
\text { - reducing project activity risks; } \\
\text { - speed of reaction to changes; } \\
\text { - quality of project knowledge } \\
\text { (compliance with the conditions of the } \\
\text { external environment). }\end{array}$} \\
\hline & - generating benefits; & \\
\hline & - creating a value proposition; & \\
\hline & - creation of a strategy; & \\
\hline & $\begin{array}{l}\text { - planning and implementation of the } \\
\text { policy }\end{array}$ & \\
\hline & - controlling; & \\
\hline & $\begin{array}{l}\text { - perception and response to the } \\
\text { external environment }\end{array}$ & \\
\hline \multirow{6}{*}{$\begin{array}{l}\text { Personal } \\
\text { approach }\end{array}$} & - the skills of the employees; & \multirow{6}{*}{$\begin{array}{l}\text { - emotional and behavioral employee } \\
\text { loyalty (satisfaction); } \\
\text { - level of individual competence of } \\
\text { employees; } \\
\text { - sustainability of interaction with } \\
\text { partners; } \\
\text { - quality of project knowledge } \\
\text { (compliance with the conditions of the } \\
\text { external environment). }\end{array}$} \\
\hline & - personal and professional qualities; & \\
\hline & - project skills; & \\
\hline & - qualification and professionalism; & \\
\hline & - ability to work in a team; & \\
\hline & - motives and needs; & \\
\hline \multirow{7}{*}{$\begin{array}{l}\text { Competitive } \\
\text { approach }\end{array}$} & $\begin{array}{l}\text { - project knowledge and } \\
\text { competencies; }\end{array}$ & \multirow{7}{*}{$\begin{array}{l}\text { - company's market share / market } \\
\text { share growth rate; } \\
\text { - sustainability of the brand; } \\
\text { - level of stakeholder satisfaction; } \\
\text { - level of design software; } \\
\text { - quality of project knowledge } \\
\text { (compliance with the conditions of the } \\
\text { external environment). }\end{array}$} \\
\hline & $\begin{array}{l}\text { - strategy of the organization in the } \\
\text { field of personnel management; }\end{array}$ & \\
\hline & $\begin{array}{lll}\text { - } & \text { methods and forms of } \\
\text { communication; } & & \\
\end{array}$ & \\
\hline & - information support; & \\
\hline & - software and technologies; & \\
\hline & - positioning; & \\
\hline & - strategic planning & \\
\hline
\end{tabular}

According to the personal approach, the organization's competence in project management consists of the education, experience and skills of each employee, used in interaction with the education, experience and skills of other employees (collective competence consists of the best, leading individual competencies that are manifested in the interaction between employees of the enterprise).

According to the competitive approach, the organization's competence in project management includes individual, collective knowledge and information used by the firm to improve the organization's competitiveness. A firm has project competence if it is able to consistently provide a high level of customer satisfaction through the development and implementation of effective projects/programs/portfolios.

The process of applying the project management methodology is associated with solving various kinds of problems that arise both within the organization itself and from the external environment. 
Figure 1 shows the mechanism for assessing the level of competence of an organization in the field of project management.

The presented mechanism should be divided into 5 main blocks:

1) Analysis of the organization's current market position

Analysis of the company's position in the market includes:

- market analysis (size, dynamics, structure, market trends, profitability level);

- analysis of the main competitors, their strengths and weaknesses, and marketing strategy;

- analysis of competition and key success factors;

- market segmentation and analysis of major consumer segments by product types;

- determining the company's market share and its dynamics;

- analysis of the company's products and assortment;

- analysis of the company's marketing strategy and sales;

- analysis of the company's strengths and weaknesses.

2) Determining the level of individual competence (competence of individual employees engaged in the field of project management)

The assessment of the organization's competence begins with an estimation of the level of individual competence of employees, т.K. персонал since the staff is the main carrier of competence in the field of project management. The objectives of assessing the level of individual competence are:

- establishing compliance of employee's competence with the requirements of the position and the organization's strategy;

- satisfaction the employee's need to evaluate their own work and potential;

- establishing feedback with an employee on professional, organizational, and other issues.

34 people took part in the questionnaire to assess the level of individual competence of employees of L.L.C. «Dvizhenie-Avtomasla» (management of the organization and middle managers).

The results of the assessment of the level of individual competence of employees of L.L.C. «Dvizhenie-Avtomasla» are presented in table 3.

Table 3. Assessment of the level of individual competence of employees.

\begin{tabular}{|l|c|c|}
\hline \multirow{2}{*}{ Elements of competence } & \multicolumn{2}{c|}{ The average rating of employees } \\
\cline { 2 - 3 } & Knowledge & Experience \\
\hline $\begin{array}{l}\text { Management objects and contextual competence } \\
\text { elements }\end{array}$ & 5.45 & 5.11 \\
\hline $\begin{array}{l}\text { Management subjects and elements of behavioral } \\
\text { competence }\end{array}$ & 6.37 & 6.38 \\
\hline $\begin{array}{l}\text { Management processes and elements of technical } \\
\text { competence }\end{array}$ & 5.9 & 5.82 \\
\hline $\begin{array}{l}\text { Additional (national) elements of General } \\
\text { competence }\end{array}$ & 3.9 & 3.63 \\
\hline Average value of knowledge and experience & 5.41 & 5.24 \\
\hline
\end{tabular}

The highest / lowest ratings of knowledge and experience were given for the following elements of competence (table 4):

Figure 2 shows the results of self-assessment for the main groups of competence in relation to the expected and ideal levels of individual competence of employees in the field of project management. 


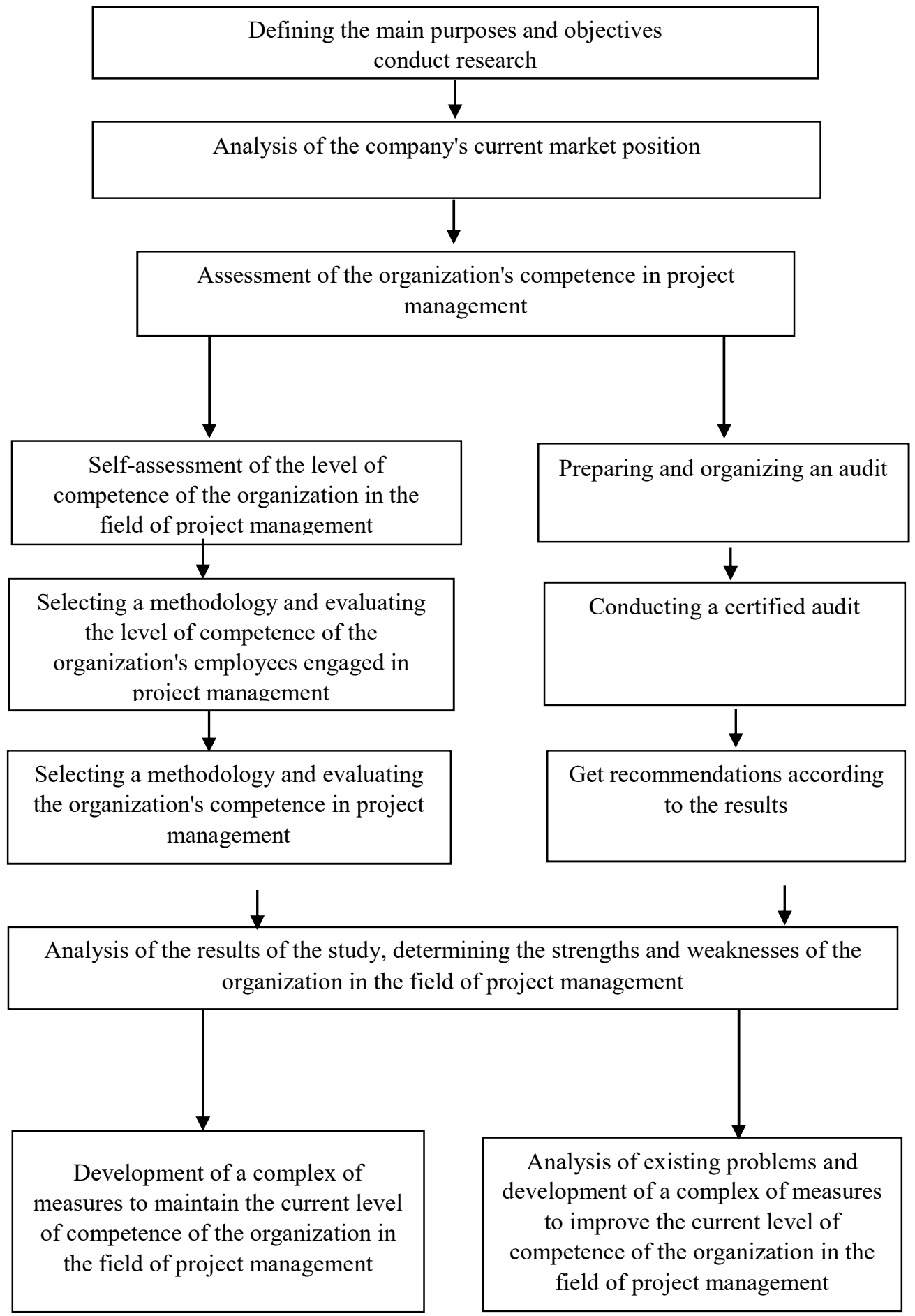

Fig. 1. Mechanism for assessing the level of competence of an organization in the field of project management. 
Table 4. Minimum and maximum estimate for competence elements.

\begin{tabular}{|l|c|c|}
\hline \multicolumn{1}{|c|}{ Elements of competence } & Knowledge & Experience \\
\hline Maximum estimate & 7.2 & 7.4 \\
\hline Creative approach & 7 & 7.1 \\
\hline Focus on results & 7.1 & 7.2 \\
\hline Efficiency & 7 & 7.3 \\
\hline Conversation & 7.5 & 7.5 \\
\hline Information and documents & 4.1 & 4.0 \\
\hline \multicolumn{2}{|c|}{ Minimum estimate } & 3.0 \\
\hline System methodology for project management & 3.5 & 3.6 \\
\hline $\begin{array}{l}\text { Organizational and technological maturity of the company in } \\
\text { the field of project management }\end{array}$ & 3.8 & 3.9 \\
\hline History and trends of project management development & 4.2 & 4.2 \\
\hline Features of project management in a crisis & 4.4 & 4.3 \\
\hline Program & 4.5 & \\
\hline Portfolio & &
\end{tabular}

As shown by the results obtained, the level of individual competence (both average and for each of the competence groups) of employees « Dvizhenie-Avtomasla» is below the desired level. The closest to the expected level are indicators of behavioral competence of employees (both knowledge and experience), in turn, the lowest indicators are the general competence of employees.

3) Assessment of the organization's competence in project management

The assessment of the organization's competence in the field of project management should be based on the model of organizational maturity of project management used to assess the current state of the project management system and determine the strategy and tactics for the development of this system in the organization.

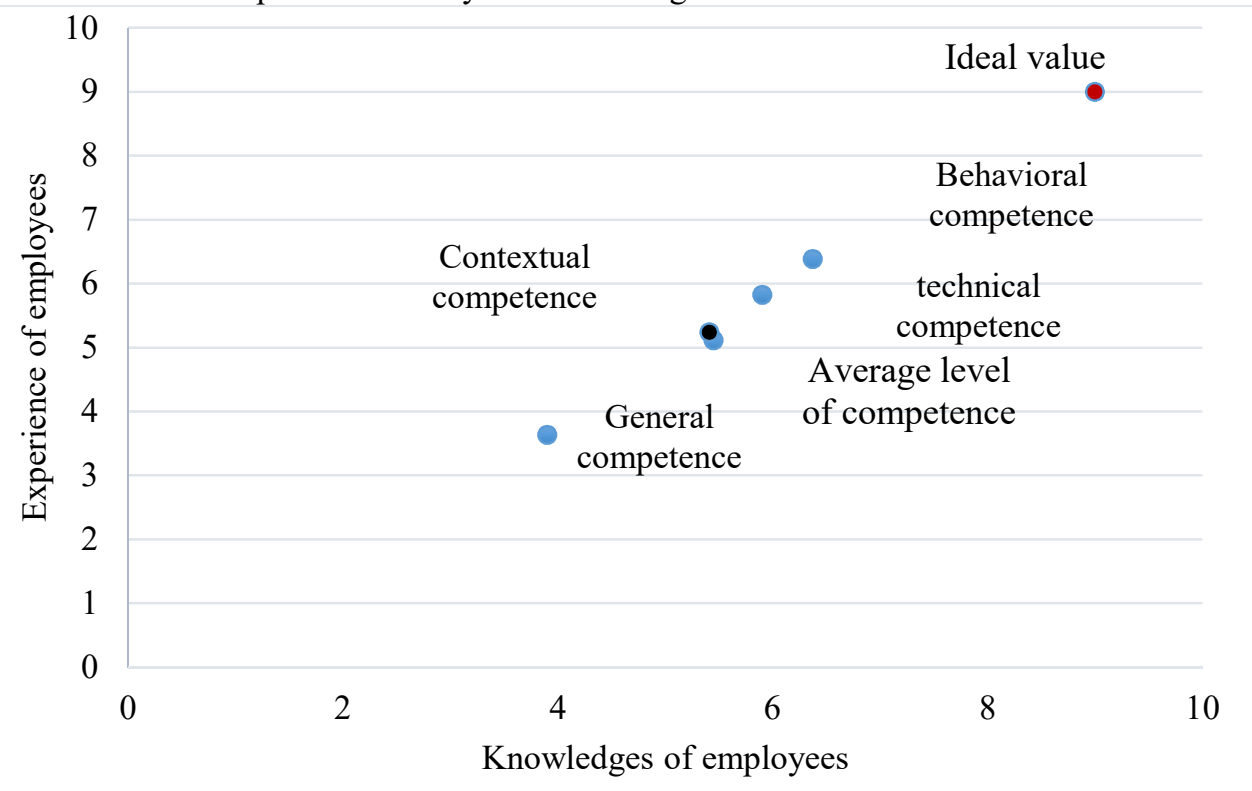

Fig. 2. Assessment of the level of individual competence.

This model is based on a two-dimensional structure:

- the first dimension reflects the level of maturity of the organization (table 5); 
- the second dimension displays the key areas of project management (manual PMBOK $($ ): project integration management, content management, timeline management, cost management, quality management, human resource management, project communications management, risk management, procurement management, stakeholder management [9].

The assessment of the level of maturity for the ten project management areas under consideration is carried out using a questionnaire survey of the organization's management.

Characteristics of maturity levels are described in the table 5.

The following conclusions are based on the results obtained:

- timeline management, quality management, and stakeholder management are at the beginning of the transition from the "initial process" level to the "structured process and standards" level» almost;

- risk management, project communication management, project integration management, and content management are at the second level of maturity ("structured process and standards»);

- human resource management in the organization is at the very beginning of its formation at the level of maturity "organizational standards and institutional process».

- cost management and procurement management have a robust position at the third level " organizational standards and institutional process»».

Table 5. Maturity levels of an organization in project management $[15,16,17]$.

\begin{tabular}{|l|l|}
\hline \multicolumn{1}{|c|}{$\begin{array}{c}\text { Level of } \\
\text { maturity }\end{array}$} & \multicolumn{1}{c|}{ Characteristics of the level } \\
\hline $\begin{array}{l}\text { 1. Initial } \\
\text { process }\end{array}$ & $\begin{array}{l}\text { The organization does not have formally accepted project management } \\
\text { procedures, project execution is not planned, and project activities are poorly } \\
\text { defined in terms of content, volume, and cost. Project management processes } \\
\text { are completely unpredictable and poorly controlled. Top management often } \\
\text { does not understand the key issues of project management, so success depends } \\
\text { more on individual efforts than on the organization of project management } \\
\text { processes. }\end{array}$ \\
\hline $\begin{array}{l}\text { 2. Structured } \\
\text { process and } \\
\text { standards }\end{array}$ & $\begin{array}{l}\text { In organizations governed by their own formalized procedures of project } \\
\text { management. The project management processes are recognized and controlled } \\
\text { by project managers partially. However planning and management depends on } \\
\text { the head individual approach in each specific project. }\end{array}$ \\
\hline $\begin{array}{l}\text { 3. Organizational } \\
\text { standards and } \\
\text { institutional } \\
\text { process }\end{array}$ & $\begin{array}{l}\text { It involves a partial formalization of project management processes and the } \\
\text { usage of a basic project planning and management system in the organization. } \\
\text { Organizations that have reached this level take a systematic and structured } \\
\text { approach to project planning and control. Project personnel are trained to } \\
\text { understand and apply project management methodologies and tools. }\end{array}$ \\
\hline $\begin{array}{l}\text { 4. Controlled } \\
\text { process }\end{array}$ & $\begin{array}{l}\text { The organization has full formalization and approval of all project } \\
\text { management processes and documentation of all relevant information. }\end{array}$ \\
\hline & $\begin{array}{l}\text { Project management processes are constantly improving in the company. It } \\
\text { provides automatic collection of project management data to identify } \\
\text { weaknesses in processes, analyse of them, and quantify them to identify } \\
\text { opportunities for continued improvements in project management processes. } \\
\text { This level implies the availability and usage of tools for continuous } \\
\text { improvement of project management processes. }\end{array}$ \\
\hline $\begin{array}{l}\text { 5. Process } \\
\text { optimization }\end{array}$
\end{tabular}

Thus, it can be noted that the level of competence of most areas of project management in the company «Dvizhenie-Avtomasla» is below the desired level for effective functioning in the project area (, indicators for each of the 10 project management areas must be at least at the level of maturity "organizational standards and institutional process" for effective functioning, while «managed process» is the recommended level). 
4) Determining the level of competence of the organization in the field of project management by conducting an audit.

Another option for determining the level of individual competence and competence of the organization in the field of project management is the competence audit. Competence audit is a periodic comprehensive research of the firm's sources of competence and their interaction in order to identify hidden potential, as well as to developing of action plan to increase the level of competence of the organization in the field of project management.

Competence audits can be performed regularly (1-3 times a year) or as required. Initiating a competency audit is appropriate for the following problems [18, 19]:

- low competitiveness (or its decline) of the organization;

- the organization has a lack of knowledge about modern technologies in the field of project management;

- strategic planning in project management is done intuitively or not at all;

- there is a high turnover of personnel, which is associated with the loss of customers or the threat of disruption of the deadlines for the execution of orders;

- employees experience an overabundance of information when it is poorly structured and difficult to find the necessary data;

- significant investments are planned in programs of employee promotions, engaged in project management.

5) Development of a complex of measures based on the results obtained.

The study provides an idea of the current level of individual competence and competence of the organization as a whole, as well as the level of maturity of project management in the organization. The results obtained make it possible to identify problems in the project activity and identify key consequences.

Figure 3 shows the level of individual competence and the competence of the organization (levels are defined as a percentage of the ideal value of these indicators).

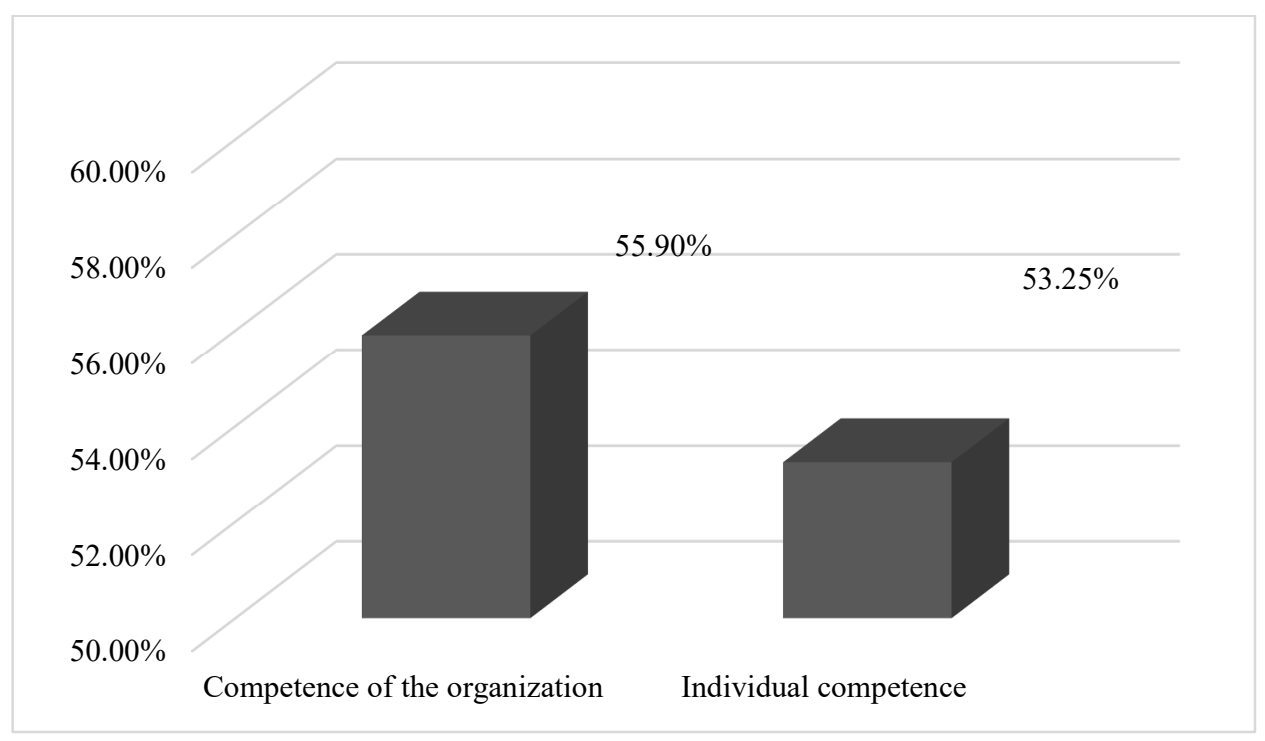

Fig. 3. Level of competence.

The level of competence of the organization and the level of individual competence of employees are approximately equal and are at an average level (indicators are closer to the level of low competence). 


\section{Discussion}

The next step is to developing a model of key competencies for employees, engaged in project management after determining the level of competence of the organization's employees (using the SOVNET method) [19]. The presented model includes 5 main areas:

1. General management skills (includes employee knowledge, skills and abilities in areas such as organizational behavior, law, finance, operational management, change management, etc.)

2. Software for project management (includes the main tools used by organizations in the process of project development and implementation)

3. Soft-competencies in project management (include basic skills and knowledge in the field of project management)

4. Hard-competencies in project management (include standards and tools used in project management)

5. Development of project management (includes key features of designing, building and developing a corporate project management system and project management methodology in the organization).

The process of selecting and developing an effective competence development strategy is specific to each individual subject. The considered model is quite generalized, and each organization is unique and must to adapt the competence development strategy taking into account its own characteristics and the level of project maturity.

In particular, a project management development program was proposed for organization «Dvizhenie-Avtomasla», which includes the following activities:

- professional training and professional development of employees in accordance with the organization's objectives in the project area;

- creating or allocating a specialized project management unit;

- development and implementation of normative and methodological documents in the organization's activities: the organization's policy in the field of project management, unified templates for project management;

- development and implementation of project management information system.

\section{Conclusions}

The formation and development of an organization's competence in project management requires continuous development. Management can use experienced consultants to implement it. Organizations can build and develop their competence in project management through the implementation of the competence building and development program.

The implementation of the program for the development of employee's project competence and the organization as a whole allows the company:

- to improve employee's skills in project activities;

- to implement projects of various complexity and scale with minimal involvement of external organizations;

- to improve the efficiency of using the organization's resources;

- to improve the quality of services and financial performance of the organization;

- to improve the company's market position.

The devised method of diagnostics and development of organization's competence in the field of project management can be modified for specifics of activities of a particular organization, and namely to modify the questionnaire for the assessment of individual competence and the competence of the organization as a whole based on the size of the company, operation specifications, and the frequency of project's implementations. 


\section{References}

1. D. Raven, Competence in modern society. Identification, development and implementation (Kogito-Centre, Moscow, 2002)

2. C. Velde, Proceedings of the XXVII Annual SCUTREA Conference, 27-35 (1997)

3. A.V. Khutorsky, Public education 2, 58-64 (2003)

4. Project Manager Competency Development Framework (PMCDF $®)$

5. International standard ISO/IEC 17024. Conformity assessment. General requirements for personnel certification authority

6. IPMA Organizational Competence Baseline. Requirements for the organization's competence in project management (Project practice», Moscow, 2014)

7. A.K. Kupeshev, A.R. Shalbaeva, Science and education in XXI century: collection of scientific papers on materials of International scientific and practical conference, 101104 (2013)

8. Y.N. Solovyova, Marketing competence management - Master's textbook (SaintPetersburg, 2015)

9. A. Mottaeva, , E3S Web of Conferences, 110, 02166, (2019) doi.org/10.1051/e3sconf /201911002166

10. A.V. Koryakin, N.N. Kataeva, Collection of materials XII International student scientific and practical conference «Economic aspects of Russia's development: microand macrolevels» (Vyatka state University, Kirov, 2019)

11. O.V. Toporova, N.N. Kataeva, Nauka-Rastudent.ru 2, 35 (2016)

12. O.A. Sapegina, Collection of materials XII International student scientific and practical conference 1(47), https://sibac.info/archive/economy/

13. Project management. Basics of professional knowledge. National requirements for professional competence (Project practice, Moscow, 2010)

14. N. Kataeva, I. Marakulina, Y. Snigireva, S. Barinov, Web of Conferences International Science Conference SPbWOSCE-2017 "Business Technologies for Sustainable Urban Development", 01046 (2018)

15. K.Y. Titova, Strategy for sustainable development of Russian regions 4, 98-101 (2013)

16. O.A. Xarchenko, L.I. Gorchakova, Science week SPbPU: materials of the scientific forum with international participation, 323-326 (2015)

17. Website PMI, https://www.pmi.org/learning/library/pm-maturity-industry-wideassessment-9000

18. L.A. Avdeeva, K.M. Musabirova, Online journal « Science of science» 8.1(32), 60 (2016)

19. D.S. Karimova, Strategic and project management: collection of scientific articles of Perm state national research University (L.L.C. «Parma-Telecom», Perm, 2012) 